\title{
Effects of urbanisation and landscape heterogeneity mediated by feeding guild and body size in a community of coprophilous beetles
}

\author{
Christopher W. Foster ${ }^{1}$ (D) $\cdot$ Christopher Kelly $^{1} \cdot$ Jordan J. Rainey $^{1} \cdot$ Graham J. Holloway $^{1}$ (D) \\ Published online: 17 April 2020 \\ (C) The Author(s) 2020
}

\begin{abstract}
Although the impacts of urbanisation on biodiversity are well studied, the precise response of some invertebrate groups remains poorly known. Dung-associated beetles are little studied in an urban context, especially in temperate regions. We considered how landscape heterogeneity, assessed at three spatial scales (250, 500 and $1000 \mathrm{~m}$ radius), mediates the community composition of coprophilous beetles on a broad urban gradient. Beetles were sampled using simple dung-baited traps, placed at 48 sites stratified across three distance bands around a large urban centre in England. The most urban sites hosted the lowest abundance of saprophagous beetles, with a lower mean body length relative to the least urban sites. Predicted overall species richness and the richness of saprophagous species were also lowest at the most urban sites. Ordination analyses followed by variation partitioning revealed that landscape heterogeneity across the urban gradient explained a small but significant proportion of community composition. Heterogeneity data for a 500-m radius around each site provided the best fit with beetle community data. Larger saprophagous species were associated with lower amounts of manmade surface and improved grassland. Some individual species, particularly predators, appeared to be positively associated with urban or urban fringe sites. This study is probably the first to examine the response of the whole coprophilous beetle community to urbanisation. Our results suggest that the response of this community to urbanisation matches expectations based on other taxonomic groups, whilst emphasising the complex nature of this response, with some smaller-bodied species potentially benefitting from urbanisation.
\end{abstract}

Keywords Urban gradient · Landscape heterogeneity · Dung beetles · Community analysis

\section{Introduction}

Urbanisation is among the foremost threats to biodiversity, with an increasing proportion of the global human population living in cities (United Nations 2014). Yet it is this high population density that makes urban green spaces a key point of interaction between humans and wildlife, driving the need for researching biodiversity in urban areas (Niemelä 1999). Key to this is understanding how functional traits drive community assembly. Urban species communities may be filtered by traits, at a regional scale (Croci et al. 2008a; Vallet et al. 2010), with a consequential reduction in phylogenetic diversity (Knapp et al. 2008). At a local level (i.e. along a single

Christopher W. Foster

c.w.foster@ reading.ac.uk

1 Centre for Wildlife Assessment and Conservation, School of Biological Sciences, University of Reading, Reading, UK urban gradient) the community composition may be more randomly structured (Magura et al. 2018) and not necessarily filtered by the same traits as at a regional scale - potentially threatening ecosystem function (Croci et al. 2008a; Magura et al. 2018).

Historically, much urban biodiversity research concerned birds, which undergo significant community homogenisation and restructuring along gradients of urbanisation (Baker et al. 2010; Gagné and Fahrig 2011). An increasing number of studies address invertebrates in urban areas (Jones and Leather 2012) and show that the response to urbanisation is far from uniform, varying both within and between taxonomic groups (McIntyre et al. 2001; Gibb and Hochuli 2002; Angold et al. 2006; Egerer et al. 2017) and mediated by factors such as body size (Magura et al. 2006), feeding guild (Hochuli et al. 2004; Magura et al. 2013), degree of specialism (Gaublomme et al. 2008) and mobility (Angold et al. 2006; Snep et al. 2006; Delgado de la Flor et al. 2017).

These non-uniformly negative impacts mean that urban greenspaces can host a diverse range of species (Angold 
et al. 2006), and ecosystem function is not necessarily impaired by urbanisation beyond its fragmentation of habitats (Wolf and Gibbs 2004). Bee diversity can be particularly high in urban green spaces (Lowenstein et al. 2014; Baldock et al. 2015; Banaszak-Cibicka et al. 2018), suggesting that urban areas may contribute to maintaining pollination services across the wider landscape (Theodorou et al. 2017). Pest regulation may also be supported by the relatively high diversity of open-habitat spiders (Lövei et al. 2019). This highlights that urban areas are an important part of the contemporary landscape mosaic and their 'spillover' effect into agricultural landscape or neighbouring semi-natural habitats, whether positive or negative, needs to be addressed.

Some argue that by hosting novel ecosystems (Hobbs et al. 2009; Kowarik 2011) urban areas actually boost overall biodiversity at a broad landscape scale, e.g., regional or national (Sattler et al. 2011). Species communities in a habitat patch may even be modified by the presence of urban areas in the surrounding landscape (Neumann et al. 2016a). To assess the full effect of landscape heterogeneity on biodiversity, including how urban areas interact with other land cover types, ideally a measure of gamma diversity would be obtained, i.e., the species diversity of the whole landscape. However, studies that address this are not particularly common (Duflot et al. 2014, 2017). Though not a complete substitute, sampling insects on ecotones using a common attractant, such as baited traps or flowers (e.g. Foster et al. 2019), may provide a snapshot of landscape biodiversity that can be assessed at a large number of sites relatively easily. Such a method can be carried out in urban sites as well as rural, where a habitat-focussed experimental design is not always feasible. It may also facilitate focussing on a particular functional group, which may be a more meaningful measure for assessing the value of urban greenspaces than the more random assemblages of species collected by passive trapping methods (Gagic et al. 2015; Pinho et al. 2016).

Scarabaeoidea are a well-studied group, especially the true dung beetles in the families Geotrupidae and Scarabaeidae subfamilies Aphodiinae and Scarabainae (henceforth 'dung beetles'). Dung beetles are important ecosystem-service providers in pastoral agricultural systems (Nichols et al. 2008; Manning et al. 2016) and often used as indicators in tropical ecosystems (Nichols et al. 2007), where they are threatened by habitat fragmentation including urbanisation (Korasaki et al. 2013). They are usually sampled using a variety of dungbaited trapping techniques or by direct searching of dung. Very few studies consider dung beetles in an urban context (Ramírez-Restrepo and Halffter 2016). Not all dung-feeding Scarabaeoidea are obligate dung feeders (Gittings and Giller 1997) and some will feed on dog dung, even preferentially so for species that prefer omnivore to herbivore dung (Cave 2004; Carpaneto et al. 2005). As such, a stable community of dung beetles might persist in urban green spaces that provide either a ready supply of dung or other sources of rotting organic material for species with broadly saprophagous larvae. In addition, other beetles besides Scarabs are coprophilous, attracted to dung either as a direct food source or to predate on the eggs and larvae of other insects (Hanski and Cambefort 1991). Many of these species belong to the Staphylinidae, which despite potentially being a good indicator group (Bohac 1999; Vásquez-Vélez et al. 2010) are less often the focus of urban or landscape studies (though see Delgado de la Flor et al. 2017; Magura et al. 2013; Vergnes et al. 2014).

In this study, we use simple baited traps to sample the coprophilous beetle community in and around a large urban area in southern England. By stratifying sampling sites into three urban distance bands, we investigated the effect of proximity to urban land cover. We expected the most rural sites to contain more resources for coprophilous beetles (due to higher density of both wild mammals (Baker and Harris 2007) and livestock) and therefore test the hypotheses that i) coprophilous beetle abundance and ii) species richness are highest at rural sites and lowest at urban sites. As urbanisation filters out larger species and habitat specialists in some other groups of beetles (Magura et al. 2010; Merckx et al. 2018), we also test the hypotheses that iii) beetles collected at urban sites will have a lower average body size than at rural sites and iv) community composition differs between urban distance bands. We examine the response of predatory and saprophagous species separately, anticipating that predators may be more able to exploit alternative habitat resources to dung. Finally, we explore the effect of landscape heterogeneity on the beetle community using ordination analyses, identifying the key landscape elements and the spatial scales at which they most strongly influence community composition in coprophilous beetles.

\section{Methods}

\section{Study design}

Forty-eight study sites were selected on woodland edges or the perimeters of partly wooded urban green spaces (edges $>50 \mathrm{~m}$ in length). Whilst sampling may therefore be biased towards edge-preferring (or edge-tolerating) species, we considered this appropriate as the highly heterogeneous urban sites provided very little interior habitat. Sampling along edges was also designed to capture species preferring both open and shaded habitats, rather than confine the species pool under consideration to a single habitat. Overall abundance and diversity can be higher at habitat edges (Magura et al. 2017) though some dung beetle species may avoid ecotones (Martínez-falcón et al. 2018). 
Study sites were selected in three groups based on their distance from Reading, a town at the centre of a large conurbation (area $83.7 \mathrm{~km}^{2}$, population c. 340,000 (Brinkhoff 2018)) in southern England (lat. 51.45, long. -0.97). A circular area with a $15 \mathrm{~km}$ radius originating at the town centre was divided into eight sections following compass intervals, e.g., the area between bearings north and northwest. In each of the eight sections six sites were selected. Two of the six were 'Urban' sites, defined as being less than $200 \mathrm{~m}$ from the main Reading conurbation, as mapped in Land Cover 2007 (Morton et al. 2011). Two were 'Fringe' sites, between $200 \mathrm{~m}$ and $1000 \mathrm{~m}$ away from either the Reading conurbation or other urban areas $>10$ ha in extent. Finally, two 'Rural' sites were selected, all of which were $>1000 \mathrm{~m}$ away from any urban area $>10$ ha. Urban, Fringe and Rural are henceforth referred to as urban distance bands. All selected sites were at least $1 \mathrm{~km}$ from their nearest neighbour to maximise independence between beetle populations. During fieldwork, site locations occasionally had to be changed to find a suitable place to set traps. Sites were subsequently recategorised after fieldwork was complete, again according to the distance bands above but using the precise field survey locations and updated urban land cover data from Land Cover 2015 (Rowland et al. 2017). This resulted in a final sample of 15 'Urban' sites, 16 'Fringe' sites and 17 'Rural' sites (Fig. 1).

\section{Beetle sampling}

Due to the high likelihood of trap disturbance in the urban sites, we assessed the dung-attracted beetle community using simple baited traps deployed for a short time period. Traps consisted of a $140 \mathrm{~mm}$ wide, $20 \mathrm{~mm}$ deep Petri dish filled to the brim with horse dung, which is attractive to a wide variety of species (Mroczyński and Komosiński 2014). Dung was collected early in the morning from an enclosed stable in order to reduce the potential for colonisation by beetles ahead of its use for sampling (Krell 2007). Between collection and use for trapping, the dung was kept inside in a covered bucket to keep it moist and exclude insects. Blends of dung collected on three different days were used to fill the traps in order to reduce variability in the age and consistency of dung provided between sampling sites. Any dung older than three days was discarded and not used for sampling since dry dung is less attractive to dung beetles (Aschenborn et al. 1989; Hanski and Cambefort 1991) and possibly other coprophilous beetles.

Sampling sites were visited twice each between 19th May 2015 and 25th July 2015 in dry, calm conditions. Two randomly selected sites in each urban distance band were visited on each day of fieldwork. On the day, sites were visited in a random order to further reduce collinearity between weather or time of day and urban distance. Four traps were set out in a line at each sampling location, following a woodland edge or other semi-natural habitat boundary. Traps were placed on the ground at least $10 \mathrm{~m}$ apart. Presence/absence of livestock at the sampling location was also recorded during sampling as dung availability is known to modify the efficacy of dungbaited traps (Finn et al. 1998). After one hour, traps were sealed using the petri dish lid and returned to the laboratory.

Trap contents were emptied into a bucket of water to float out any adult beetles present, which were removed using a small sieve. Beetles were stored in $70 \%$ ethanol prior to identification. Beetles were identified to species following the relevant identification literature (Lott 2009; Lott and Anderson 2011; Duff 2012; Dung Beetle UK Mapping Project 2018). Members of the family Ptilidae and subfamily Staphylinidae: Aleocharinae were counted a maximum of once each towards the species total for each site but not identified to species for use in community analysis. We used double-blind identification for quality control. Where necessary, specimens were dissected to confirm identification and compared to reference material in the Oxford University Museum of Natural History (Specimens for this study are held in the Centre for Wildlife Assessment and Conservation at the University of Reading and available to view on request). Species were split into larval feeding guilds based on expert information held in the PANTHEON database (Webb et al. 2018). The majority fell into one of two groups, either saprophagous (feeding on rotting organic material including dung) or predatory. They were also assigned an average body length from information provided in the identification resources for each family.

\section{Landscape data for ordination analysis}

\section{Spatial scale, landscape variables}

Dung beetles in pasture habitat generally remain within the field in which they emerged (Roslin 2000), though dispersal of individuals is leptokurtic, with some $1 \%$ of marked beetles observed by Roslin (2000) found $1 \mathrm{~km}$ away. If the appropriate spatial scale at which to examine the effects of landscape heterogeneity can be drawn from recorded dispersal flight distances, evidence from other beetle families is mixed. Irmler et al. (2010) reported very few saproxylic beetle species in flight intercept traps $>80 \mathrm{~m}$ from woodland, whereas Doležal et al. (2016) observed a maximum movement in a bark beetle of over $1 \mathrm{~km}$. The harlequin ladybird Harmonia axyridis may be capable of regular dispersal flights $>18 \mathrm{~km}$ (Jeffries et al. 2013), so clearly some beetles are unlikely to be impacted by habitat fragmentation. Most flighted rove beetles are probably highly mobile, potentially dispersing long distances assisted by weather patterns. To account for this uncertainty, landscape variables were extracted for three different scales. These were 250-m, 500-m and 1-km buffers around the centre of the sampling sites. Landscape variables are split into two conceptual categories: landscape composition, which is the amount of different land cover types, and landscape 
Fig. 1 (a) The location of 48 sampling sites in the vicinity of Reading, UK, separated into three types according to their distance from urban areas $>10$ ha. Urban areas in grey shading, blue shading denotes rivers and other bodies of freshwater. Landscape composition for a $250 \mathrm{~m}$ and $500 \mathrm{~m}$ radius around the sites (black circles) is shown for (b) an urban site, (c) a 'fringe' (periurban) site and (d) a rural site. (C) Crown copyright and database rights 2019 Ordnance Survey (100025252)
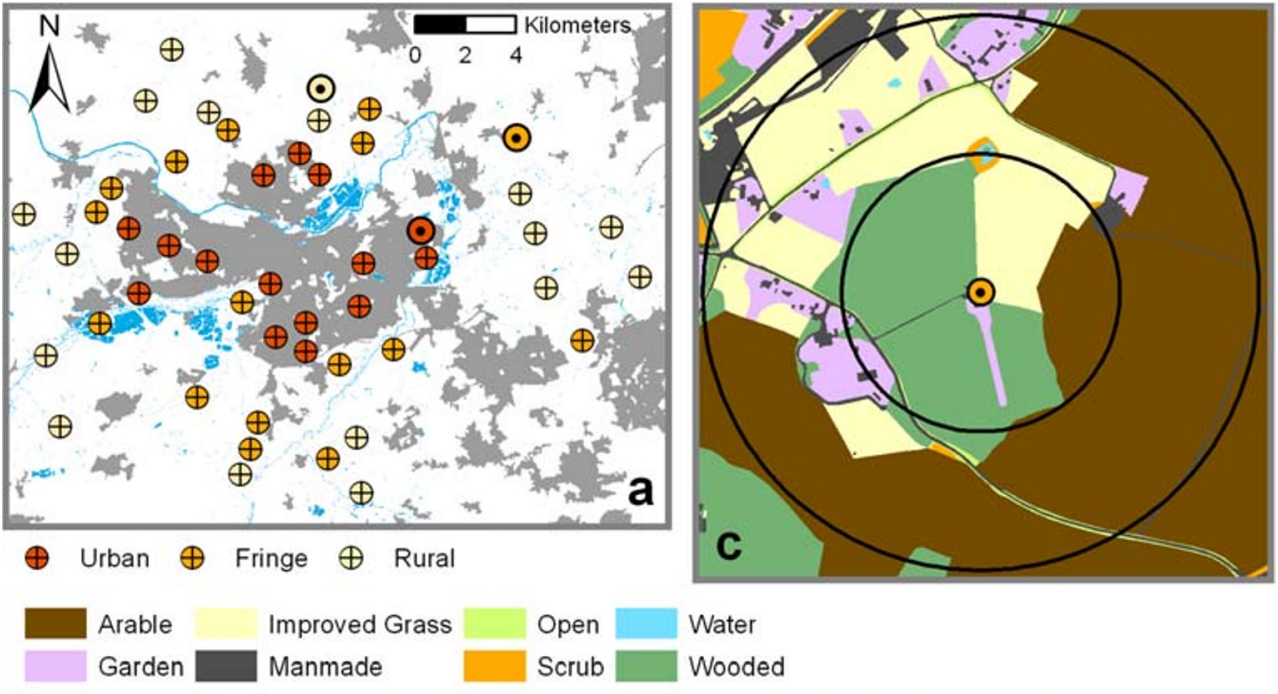

Wooded
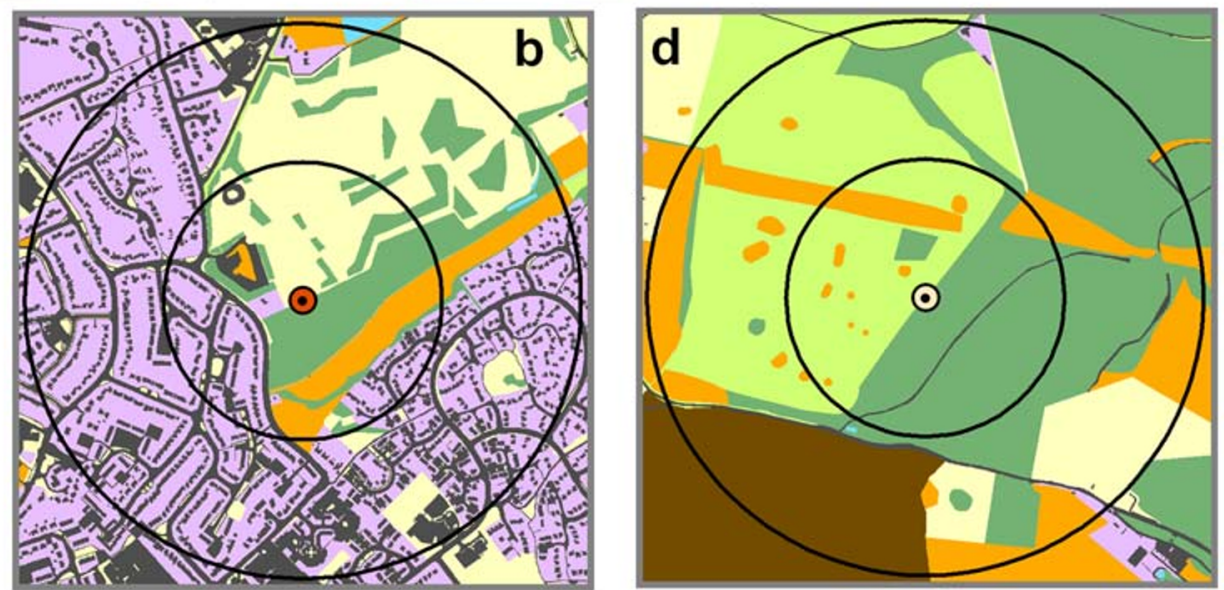

configuration, which describes the spatial arrangement of those types, i.e., heterogeneity and fragmentation.

\section{Landscape composition}

The topography of land cover patches for landscape variables was taken from OS Mastermap (Ordnance Survey 2015) and analysed in ArcGIS 10.4 (ESRI 2016). All patches intersecting 2000-m buffers around the sampling points were classified into one of eight landscape composition variables, in total comprising a complete landscape mosaic analysis. All buildings, structures, paved roads and unsurfaced tracks were classified as MANMADE. Patches listed in Mastermap as 'Make = Multiple' $(\mathrm{a}$ mixture of manmade and natural surfaces) were classified as GARDEN. Semi-natural habitat patches were classified as either WOODED (nonconiferous trees, coniferous trees, coppice), SCRUB (scrub, scattered coniferous trees, scattered non coniferous trees, orchard) or OPEN (freshwater marsh, heath, heather grassland, neutral grassland, acid grassland and calcareous grassland). Linear patches of habitat alongside railway lines were classified as OPEN. Linear patches alongside roads were also classified as
OPEN unless the underlying land cover type in LCM2015 (Rowland et al. 2017) was urban, in which case they were classified as improved or amenity grassland (IMPGRASS). Freshwater types including rivers, lakes, streams and ditches were classified as WATER. Remaining unclassified polygons with no attributes listed in OS Mastermap were assigned to a category with reference to Natural England priority habitats data (Natural England 2018) and Land Cover Map 2015 (Rowland et al. 2017), categorising agricultural land as either improved grassland (IMPGRASS) or arable/horticulture (ARABLE).

\section{Landscape configuration}

A variable estimating the availability of livestock dung (DUNGAV) in the surrounding landscape (Webb et al. 2010) was created by multiplying the area of each grassland patch (improved and semi-natural) by a 'livestock index'. The index was derived from livestock headage data (DEFRA 2010) at a $5 \mathrm{~km}^{2}$ grid cell resolution. Vales for each cell were rescaled to $0-1$ where $0=$ no livestock in the corresponding $5-\mathrm{km}^{2}$ grid 
cell and $1=$ the maximum value for any cell intersecting with the study area.

To calculate mean patch size for the semi-natural habitat categories WOOD, SCRUB and OPEN, any patches closer than $20 \mathrm{~m}$ were functionally considered to represent a single patch (Neumann et al. 2016b) and aggregated into one. Most beetles attracted to dung-baited traps are likely to arrive by flying, so gaps of this size are unlikely to present a significant barrier to dispersal. The mean size of aggregated patches that intersected the landscape buffers was then used to create the variables WOPATCH, SCPATCH and OPPATCH. Road verges were not included in the patch size calculation for OPPATCH, so this variable refers only to more extensive semi-natural grassland. As a further measure of habitat fragmentation, the mean distance to each of the three semi-natural habitats within landscape buffers was calculated, forming the variables WOODDIS, SCRUBDIS and OPENDIS. These were based on the original non-aggregated habitat patches, again excluding road verges for OPENDIS.

Finally, mean garden size (GARSIZE) was included as an alternative measure of urbanisation. Garden size tends to be smaller in core urban areas and larger in suburbs (Smith et al. 2009). Larger gardens may be more likely to contain a diverse mix of habitats, with a range of sources of decaying vegetation such as compost heaps that may provide habitat for saprophagous beetles that are also attracted to dung. A summary of all landscape composition and configuration variables and their mean values in each urban distance band is given in Table 1.

\section{Statistical analysis}

All analysis was carried out in R 3.4 (R Core Team 2017). Data from the four traps at each sampling site were pooled. Data from the two visits were considered separately when testing for differences in abundance and species number. For species richness estimates and all community analyses, data from the two visits were pooled into a single value for each site.

\section{Landscape variables, abundance, species richness and mean body length}

Differences in the values of i) landscape variables, ii) beetle abundance, iii) species number and iv) mean body length between urban distance bands were assessed using KruskalWallis tests (adjusted for ties), followed by Dunn's test for multiple comparisons with Bonferroni corrected $p$ values. These were carried out using the R package 'dunn.test'.

For abundance and species richness, 12 initial KruskalWallis tests were performed, examining the abundance and species richness in visit 1 and 2 of i) all beetles ii) those with saprophagous larvae and iii) those with predatory larvae. As numbers of dung beetles appeared to strongly influence the results for saprophagous species, the abundance of these species alone during each visit were examined in two further tests.

Table 1 Summary of landscape variables determined for three spatial scales, showing the median values for sites at three distances from large urban areas. Numbers in bold are significantly different between urban distance bands (Kruskal-Wallis tests); superscript letters denote post hoc groupings

\begin{tabular}{|c|c|c|c|c|c|c|c|c|c|c|}
\hline & & \multicolumn{3}{|l|}{$250 \mathrm{~m}$} & \multicolumn{3}{|l|}{$500 \mathrm{~m}$} & \multicolumn{3}{|l|}{$1 \mathrm{~km}$} \\
\hline & & Urban & Fringe & Rural & Urban & Fringe & Rural & Urban & Fringe & Rural \\
\hline \multirow[t]{8}{*}{ Composition (ha) } & MANMADE (ha) & $3.4^{\mathrm{a}}$ & $0.5^{\mathrm{b}}$ & $0.5^{b}$ & $18.7^{\mathrm{a}}$ & $3.3^{\mathrm{b}}$ & $2.2^{\mathrm{b}}$ & $85.8^{\mathrm{a}}$ & $25.2^{\mathrm{b}}$ & $10.4^{\mathrm{b}}$ \\
\hline & GARDEN (ha) & $3.0^{\mathrm{a}}$ & $0.4^{\mathrm{b}}$ & $0.0^{b}$ & $20.8^{\mathrm{a}}$ & $1.5^{\mathrm{b}}$ & $1.2^{\mathrm{b}}$ & $99.8^{\mathrm{a}}$ & $13.6^{\mathrm{b}}$ & $9.9^{\mathrm{b}}$ \\
\hline & WOODED (ha) & 2.7 & 5.3 & 5.0 & $5.5^{\mathrm{a}}$ & $9.9^{\mathrm{ab}}$ & $16.7^{\mathrm{b}}$ & $20.9^{\mathrm{a}}$ & $35.7^{\mathrm{a}}$ & $60.7^{\mathrm{b}}$ \\
\hline & SCRUB (ha) & 2.3 & 0.5 & 1.6 & 4.1 & 4.1 & 5.9 & 12.2 & 13.0 & 23.3 \\
\hline & OPEN (ha) & 0.4 & 0.2 & 0.3 & 0.8 & 2.0 & 1.5 & 5.0 & 7.1 & 6.6 \\
\hline & WATER (m²/ha) & 433 & 347 & 86 & 0.2 & 0.3 & 0.4 & 2.6 & 1.9 & 1.2 \\
\hline & IMPGRASS (ha) & 4.6 & 5.0 & 3.6 & 11.1 & 21.2 & 13.8 & $54.0^{\mathrm{a}}$ & $106.7^{\mathrm{b}}$ & $82.7^{\mathrm{b}}$ \\
\hline & ARABLE (ha) & $0.0^{\mathrm{a}}$ & $1.7^{\mathrm{b}}$ & $0.1^{\mathrm{ab}}$ & $0.0^{\mathrm{a}}$ & $18.6^{b}$ & $9.3^{\mathrm{b}}$ & $0.0^{\mathrm{a}}$ & $74.5^{\mathrm{b}}$ & $73.8^{\mathrm{b}}$ \\
\hline \multirow[t]{8}{*}{ Configuration } & DUNGAV & 0.7 & 3.5 & 2.5 & $3.0^{\mathrm{a}}$ & $15.1^{\mathrm{b}}$ & $12.1^{\mathrm{b}}$ & $15.0^{\mathrm{a}}$ & $66.5^{\mathrm{b}}$ & $54.7^{\mathrm{b}}$ \\
\hline & WOPATCH (ha) & 0.7 & 15.8 & 16.3 & $2.8^{\mathrm{b}}$ & $3.6^{\mathrm{b}}$ & $19.9^{\mathrm{a}}$ & $2.9^{\mathrm{b}}$ & $4.8^{\mathrm{b}}$ & $14.6^{\mathrm{a}}$ \\
\hline & SCPATCH (ha) & 0.6 & 0.3 & 0.8 & 0.9 & 1.4 & 2.2 & 2.0 & 1.5 & 2.1 \\
\hline & OPРATCH (m²/ha) & 126 & 0 & 0 & 126 & 0.4 & 0.3 & 1.5 & 11.0 & 1.1 \\
\hline & WOODDIS (m) & 59 & 36 & 48 & $97^{\mathrm{a}}$ & $82^{\mathrm{ab}}$ & $63^{b}$ & $146^{\mathrm{a}}$ & $113^{\mathrm{ab}}$ & $75^{\mathrm{b}}$ \\
\hline & SCRUBDIS (m) & 76 & 99 & 83 & 114 & 128 & 125 & 155 & 156 & 143 \\
\hline & OPENDIS (m) & 274 & 288 & 383 & 386 & 338 & 353 & 665 & 466 & 352 \\
\hline & GARSIZE $\left(\mathrm{m}^{2}\right)$ & 147 & 332 & 0 & $168^{\mathrm{a}}$ & $1062^{b}$ & $1440^{b}$ & $187^{\mathrm{a}}$ & $538^{b}$ & $1425^{\mathrm{c}}$ \\
\hline
\end{tabular}


Estimated species richness for each distance band was calculated using the function 'Specpool' in the R package 'Vegan' (Oksanen et al. 2016), examining predicted species richness \pm standard error using the Jacknife, and Bootstrap methods (Smith and van Belle 1984; Palmer 1990). Estimates were made for all beetles and for those with saprophagous larvae only.

\section{Community analysis: Distance categories}

All community analyses were carried out using the R package Vegan (Oksanen et al. 2016). Permutational analysis of variance was performed using the function Adonis (with 999 permutations) in order to assess whether beetle communities differed between urban distance bands. Beetle community data were standardised using the alternative Gower measure (Anderson et al. 2006) and log base 2 transformed such that a doubling in abundance was weighted the same as a change in composition (we were equally interested in both potential modifications of the species community). Analysis of multivariate homogeneity of group dispersions using the function Betadisper was used to check whether any observed difference in community structure between distance bands might in fact be attributable to within group variation. Tests were carried out for all beetles and for each of the main feeding guilds (saprophagous or predatory) only.

\section{Community analysis: Landscape heterogeneity}

Only species occurring in four or more sites were included in the community data used for ordination analyses. The community data matrix was $\log$ transformed $\left(\log _{2}(x)+1\right.$ for $\left.x>0\right)$ (Anderson et al. 2006). Key landscape composition and configuration variables were identified via canonical correspondence analysis (CCA), followed by a forward selection procedure. Landscape composition variables were log transformed to reduce multicollinearity between predictors and ensure the influence of small but potentially important components of the landscape was not overlooked (Neumann et al. 2016a).

Six initial models were run in total, one for all landscape composition and one for all landscape configuration variables at each of the spatial scales $(250 \mathrm{~m}, 500 \mathrm{~m}$ and $1000 \mathrm{~m}$ buffers). Collinearity between predictors was tested using Variance Inflation Factors (VIF) (Neter et al. 1996) and correlation coefficients. Terms with high VIF were removed sequentially until all terms in the global model had VIF $<5.0$ and correlation coefficients were all $<0.6$ (Radford and Bennett 2007; Neumann et al. 2016b).

Forward selection to obtain a reduced model for composition or configuration at the three scales was carried out only after a significant global test of all variables $(p<0.05)$. Terms were added sequentially to the model based on their predicted contribution to adjusted- $R^{2}$ (Peres-Neto et al. 2006), and retained only if significant at $p<0.05$ (Blanchet et al. 2008). Model building stopped before the adjusted- $R^{2}$ of the reduced model exceeded that of the global model to avoid over-fitting of explanatory variables (Blanchet et al. 2008). Probability values for the global model and individual terms retained in the reduced model were estimated using Monte Carlo tests with 9999 permutation via the function Anova.cca.

A final model for each of the three spatial scales was obtained by adding all significant composition and configuration variables as predictors and removing any that were collinear by referring again to VIF and correlation coefficients. If any terms in the resulting model were still non-significant, they were considered likely to be explaining the same environmental gradient and a further forward selection procedure (without the adjusted $R^{2}$ stopping rule) was carried out to obtain a more parsimonious model. Finally, this procedure was repeated with the best fitting variables from each scale entered into a single model to obtain a final set of landscape variables that best described the beetle community composition.

\section{Spatial and temporal autocorrelation, variation partitioning}

The effects of temporal autocorrelation and livestock presence at a site were also assessed using CCA following the model selection steps above. Dates of the first and second round of sampling were entered as two continuous variables; this controls for peaks in species activity as CCA assumes a unimodal, not linear relationship. Livestock presence was a factor with two levels indicating simple presence/absence.

We tested for spatial autocorrelation by calculating Principle Coordinates of Neighbourhood Matrices based on the XY coordinates of the sampling sites. All PCNM were used as predictors in a CCA followed by a further forward selection procedure to identify significant gradients of spatial autocorrelation. The interaction between space (represented by significant PCNM), landscape (key landscape variables) and date/livestock presence was then explored using variation partitioning. This finds the unique fraction of variation explained by each set of constraints, based on their contribution to adjusted- $R^{2}$ (estimated for CCA by permutation following Peres-Neto et al. 2006). Probability values for the unique effects of space, landscape or time/dung were estimated by using partial canonical correspondence analysis to partition out the other two sets of variables, followed by Monte Carlo tests with 9999 permutations.

\section{Results}

\section{Beetle sampling}

A total of 2636 individual beetles were collected from the 48 sites, with representatives of 34 species and a further two 
groups not identified to species (Staphylinidae: Aleocharinae, Ptilidae). The 19 species recorded from four or more sites are listed in Table 2. Of these, seven belonged to the saprophagous larval guild (of which some also feed on dung as adults); the rest all had predatory larvae and Heleophorus brevipalpus are also predators as adults. Five of the top 10 most abundant species, including the two most frequently recorded, belonged to the subfamily Oxytelinae (Staphylinidae), which are often among the most abundant rove beetles in dung (Caballero and León-Cortés 2012; Mroczyński and Komosiński 2014; Yamamoto et al. 2014). Eight species of dung beetle were recorded, with four among the most widespread species. The most common, Volinus sticticus, is widespread in woodland and scrub habitats (Dung Beetle UK Mapping Project 2018).

\section{Abundance}

There was a significant difference between distance bands in visit 1 for all species with saprophagous larvae $\left(\mathrm{K}-\mathrm{W} \chi^{2}=\right.$ $11.660, p<0.01)$ but not for all beetles together $\left(\mathrm{K}-\mathrm{W} \chi^{2}=\right.$ $5.074, p=0.08$ ). For saprophagous species, numbers at Urban sites were significantly lower than at Rural sites $(z=3.414$, $p=0.001)$ but the difference between Fringe and Urban sites was not significant $(\mathrm{z}=1.718, p=0.130$;) (Fig. 2a). There was no difference in the abundance of predators between distance bands ( $\mathrm{K}-\mathrm{W} \chi^{2}=3.21, p=0.20$ ) (Fig. 2c).

During the second visit, overall beetle abundance did not differ between urban bands $\left(\mathrm{K}-\mathrm{W} \chi^{2}=1.808, p=0.40\right)$, neither did the abundance of saprophagous species (Fig. $2 \mathrm{~b} ; \mathrm{K}-\mathrm{W} \chi^{2}=$ $2.713, p=0.26$ ) or predators (Fig. $2 \mathrm{~d}$; $\mathrm{K}-\mathrm{W} \chi^{2}=0.862$, $p=0.65)$. When data for dung beetles only were examined, there was a significant difference between Rural and Urban sites, with no dung beetles at all recorded at Urban sites during the second $\operatorname{visit}\left(\mathrm{K}-\mathrm{W} \chi^{2}=7.819, p=0.02 ; \mathrm{z}=2.760, p=0.009\right.$; Table 2).

\section{Species richness}

Neither the overall species richness $\left(\mathrm{K}-\mathrm{W} \chi^{2}=3.638, p=0.16\right)$ nor the richness of saprophagous species (Fig. 2e; K-W $\chi^{2}=$ 4.939, $p=0.08$ ) was significantly different between urban bands during the first visit, though the number of dung beetle species was $\left(\mathrm{K}-\mathrm{W} \chi^{2}=8.513, p=0.01\right)$. More dung beetle species were recorded at Rural sites than Urban sites $(\mathrm{z}=$ $2.906, p=0.006$ ). There was no difference in the species richness of predators (Fig. $2 \mathrm{~g} ; \mathrm{K}-\mathrm{W} \chi^{2}=1.652, p=0.44$ ). The same pattern occurred during the second visit, with no difference between bands for total species number $\left(\mathrm{K}-\mathrm{W} \chi^{2}=1.475\right.$, $p=0.48$ ), saprophagous species (Fig. $2 \mathrm{f} ; \mathrm{K}-\mathrm{W} \chi^{2}=1.605$, $p=0.45)$ or predators $\left(\mathrm{K}-\mathrm{W} \chi^{2}=0.862, p=0.65\right)$. Between

Table 2 Species captured in dung-baited traps at four or more sites. Species in shaded rows have saprophagous larvae; the rest are predatory (Webb et al. 2018)

\begin{tabular}{|c|c|c|c|c|c|c|c|c|c|c|c|c|}
\hline \multirow[b]{2}{*}{ Family } & \multirow[b]{2}{*}{ Biplot } & \multirow[b]{2}{*}{ Species } & \multirow[b]{2}{*}{ Sites } & \multirow[b]{2}{*}{ Total } & \multicolumn{4}{|c|}{ May 19th -15 th June } & \multicolumn{4}{|c|}{ 17th June -25 th July } \\
\hline & & & & & Urban & Fringe & Rural & Total & Urban & Fringe & Rural & Total \\
\hline Staphylinidae & An.scu & Anotylus sculpturatus & 43 & 704 & 9 & 11 & 13 & 527 & 9 & 13 & 11 & 177 \\
\hline Staphylinidae & An.tet & Anotylus tetracarinatus & 40 & 1230 & 6 & 4 & 6 & 52 & 13 & 13 & 11 & 1178 \\
\hline Scarabaeidae & Vi.sti & Volinus sticticus & 29 & 218 & 4 & 10 & 13 & 197 & 0 & 3 & 6 & 21 \\
\hline Staphylinidae: & Ox.laq & Oxytelus laqueatus & 22 & 50 & 6 & 5 & 7 & 37 & 4 & 3 & 2 & 13 \\
\hline Staphylinidae: & Pl.are & Platystethus arenarius & 17 & 32 & 0 & 2 & 3 & 7 & 8 & 2 & 2 & 25 \\
\hline Hydrophilidae & Ce.hae & Cercyon haemorrhoidalis & 12 & 39 & 0 & 2 & 5 & 34 & 3 & 0 & 2 & 5 \\
\hline Hydrophilidae & Ce.mel & Cercyon melanocephalus & 11 & 30 & 1 & 1 & 3 & 20 & 1 & 2 & 4 & 10 \\
\hline Staphylinidae & Me.pro & Megarthrus prosseni & 10 & 20 & 4 & 2 & 1 & 9 & 2 & 1 & 1 & 11 \\
\hline Staphylininae & Bi.fim & Bisnius fimetarius & 9 & 28 & 1 & 3 & 4 & 26 & 0 & 1 & 1 & 2 \\
\hline Staphylinidae & An.nit & Anotylus nitidulus & 9 & 17 & 0 & 0 & 0 & 0 & 3 & 6 & 0 & 17 \\
\hline Scarabaeidae & Me.pro & Melinopterus prodromus & 8 & 16 & 1 & 3 & 4 & 16 & 0 & 0 & 0 & 0 \\
\hline Staphylininae & Ph.var & Philonthus varians & 7 & 15 & 0 & 0 & 1 & 1 & 3 & 0 & 3 & 14 \\
\hline Scarabaeidae & On.sim & Onthophagus similis & 6 & 20 & 0 & 0 & 4 & 12 & 0 & 1 & 1 & 8 \\
\hline Staphylinidae & An.inu & Anotylus inustus & 5 & 11 & 1 & 2 & 1 & 7 & 1 & 1 & 0 & 4 \\
\hline Scarabaeidae & On.coe & Onthophagus coenobita & 5 & 7 & 1 & 1 & 3 & 7 & 0 & 0 & 0 & 0 \\
\hline Helophoridae & He.bre & Heleophorus brevipalpus & 5 & 5 & 0 & 0 & 1 & 1 & 1 & 1 & 2 & 4 \\
\hline Staphylininae & Ph.mar & Philonthus marginatus & 5 & 5 & 0 & 2 & 2 & 4 & 0 & 0 & 1 & 1 \\
\hline Staphylininae & Ga.pil & Gabrius piliger & 4 & 5 & 0 & 1 & 0 & 2 & 2 & 0 & 1 & 3 \\
\hline Hydrophilidae & Ce.pyg & Cercyon pygmaeus & 4 & 4 & 1 & 1 & 1 & 3 & 1 & 0 & 0 & 1 \\
\hline
\end{tabular}



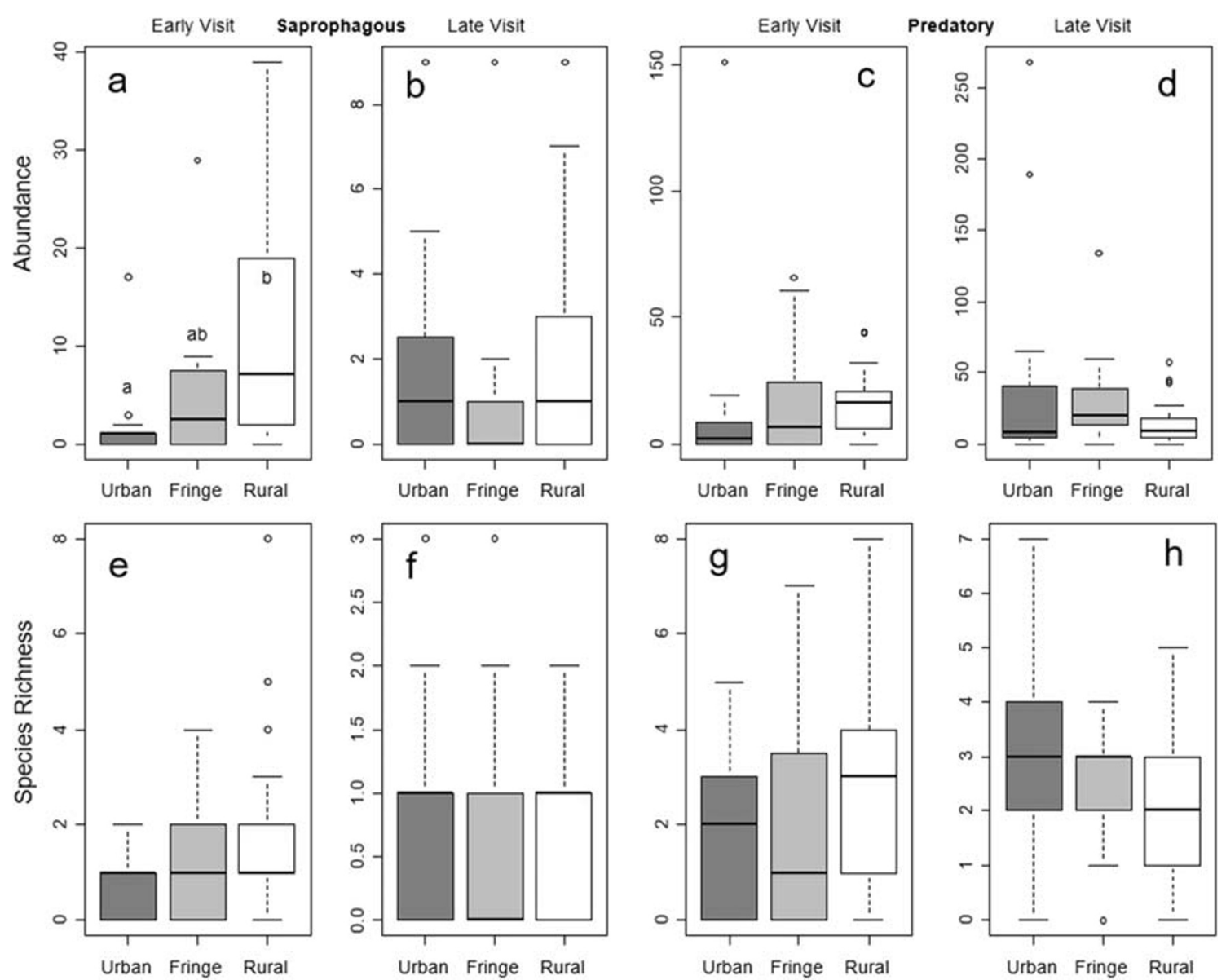

Fig. 2 Median (black bars) and inter-quartile range (shaded boxes) of (a) the abundance of saprophagous beetles during the first sampling visit, (b) abundance or saprophagous beetles during the second sampling visit, (c) abundance of predatory beetles during the first visit, (d) abundance of predatory beetles during the second visit, (e) species richness of saprophagous beetles during the first visit, (f) richness of saprophagous beetles

during the second visit, (g) richness of predatory beetles during the first visit, (h) richness of predatory beetles during the second visit. Values shown for three sets of sites grouped according to their distance from urban areas $>10$ ha. Letters denote post-hoc groupings for comparisons with significant Kruskal-Wallis test

the first and second visit patterns of species richness in predators reversed, with the highest values in Rural sites in visit 1 (Fig. 2g) and Urban sites in visit 2 (Fig. 2h).

Both estimates of species richness for urban bands predicted that Rural sites are the most species rich overall, higher than Fringe, with Urban the most species poor (Table 3), though the standard error ranges overlapped in each case. The same predicted pattern of species richness occurred for saprophagous species. The bootstrap estimate predicted that Rural sites host 50\% more saprophagous species than Urban sites, with no overlap in standard error range between Rural and Urban sites. Conversely, Rural sites are predicted to have the lowest richness of predatory species with the highest richness in Fringe sites (Table 3).

\section{Mean body length}

There was a significant difference in mean body length between distance bands in the first visit $\left(\mathrm{K}-\mathrm{W} \chi^{2}=6.033\right.$,

$p=0.05)$. Beetles at Rural sites were on average very slightly larger than those at Urban sites (Fig. 3a, z $=2.393$, $p=0.025)$. In the second visit, there was no difference in average body length between distance bands $\left(\mathrm{K}-\mathrm{W} \chi^{2}=\right.$ $1.826, p=0.40)$, driven by greater variation among Fringe and Rural sites (Fig. 3b).

Table 3 Species richness estimates \pm standard error. Highest estimates for each group are in bold text

\begin{tabular}{llrrl}
\hline & & \multicolumn{1}{l}{ Urban } & \multicolumn{1}{l}{ Fringe } & \multicolumn{1}{l}{ Rural } \\
\hline All Species & Jacknife & $34.29 \pm 3.51$ & $36.38 \pm 3.27$ & $\mathbf{3 8 . 4 1} \pm \mathbf{3 . 5 5}$ \\
& Bootstrap & $29.13 \pm 2.03$ & $31.32 \pm 2.07$ & $\mathbf{3 3 . 0 2} \pm \mathbf{1 . 8 9}$ \\
Saprophagous & Jacknife & $10.64 \pm 1.81$ & $11.69 \pm 1.84$ & $\mathbf{1 4 . 7 3} \pm \mathbf{2 . 3 1}$ \\
& Bootstrap & $8.40 \pm 0.87$ & $9.56 \pm 1.00$ & $\mathbf{1 2 . 5 4} \pm \mathbf{1 . 2 4}$ \\
Predatory & Jacknife & $19.64 \pm 2.08$ & $\mathbf{2 2 . 5 6} \pm \mathbf{2 . 8 3}$ & $18.71 \pm 2.10$ \\
& Bootstrap & $17.33 \pm 1.52$ & $\mathbf{1 8 . 9 2} \pm \mathbf{1 . 7 2}$ & $15.87 \pm 1.05$ \\
\hline
\end{tabular}




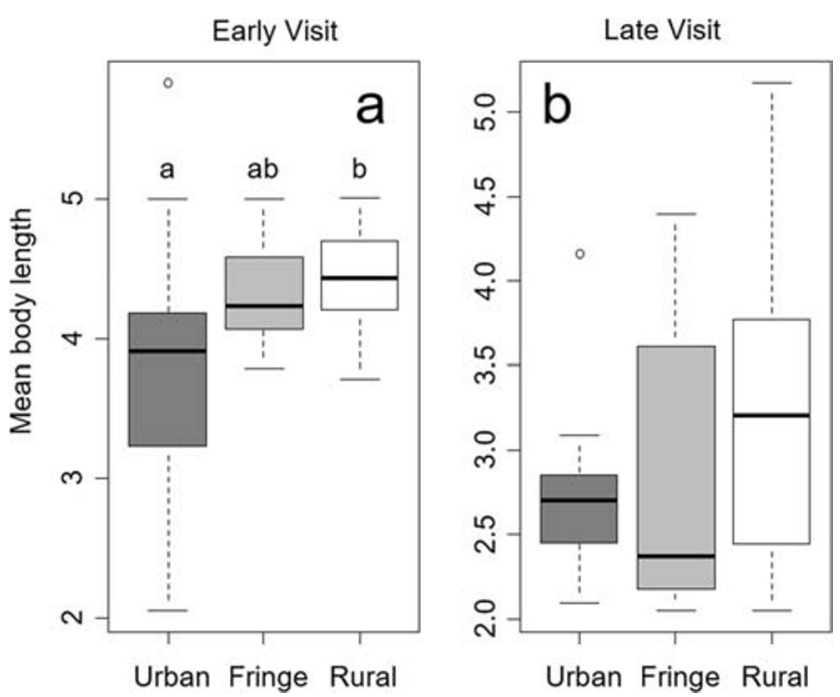

Fig. 3 Median (black bars) and inter-quartile range (shaded boxes) for mean body length $(\mathrm{mm})$ of coprophilous beetles (mean length per beetle captured, assuming average values for the species) at Urban, Fringe and Rural sites in (a) the first sampling visit and (b) the second visit

\section{Community dissimilarity}

In the permutational analysis of variance, communities were significantly dissimilar between urban band $(\mathrm{F}=1.931$, $p=0.032$ ), which explained $8.7 \%$ of the dissimilarity between sites. There was no significant difference in within band homogeneity $(\mathrm{F}=0.539, p=0.587)$. When Fringe sites were excluded, the difference between Urban and Rural sites alone explained slightly more variation $(9.1 \% ; \mathrm{F}=2.889$, $p=0.009)$. When only saprophagous species were examined, urban distance band explained $15.0 \%$ of variation between sites $(\mathrm{F}=3.174, p=0.013)$, whereas for predators urban distance band explained only $4.5 \%$ of variation between sites and was not significant $(\mathrm{F}=1.027, p=0.397)$.

\section{Landscape variables}

Cover of manmade surfaces, garden and arable land were significantly different between urban distance bands at all measured spatial scales. Woodland cover, dung availability, woodland patch size, distance between woodland patches and average garden size were all different between distance bands when measured at $500 \mathrm{~m}$ or $1 \mathrm{~km}$. Improved grassland was only significantly different at $1 \mathrm{~km}$. The highest woodland cover and patch size was around Rural sites. Manmade surface and garden cover was much higher in Urban than in Rural or Fringe sites, which were not significantly different from each other. The only variable to completely separate out the three distance bands was average garden size measured at $1 \mathrm{~km}$, for which there was a significant difference between each pair of categories (Table 1).

\section{Landscape heterogeneity: Canonical correspondence analysis}

There was a significant global effect of landscape composition and landscape configuration variables for each spatial scale (Table 4). Landscape variables measured at $500 \mathrm{~m}$ performed best in explaining variation in beetle community composition. At $250 \mathrm{~m}$ only semi-natural habitats (the size of woodland and open habitat patches) and water were identified as key variables. At $500 \mathrm{~m}$ the only semi-natural habitat variable retained was the size of scrub patches, otherwise manmade surfaces, arable and improved/amenity grassland best described the landscape in terms of beetle community response. At the $1000 \mathrm{~m}$ radius manmade surfaces were highly collinear with other variables. After MANMADE was removed from the model the extent and average size of gardens described the urban gradient whilst the extent of scrub or scattered trees was also important at this scale.

All of the variables from $500 \mathrm{~m}$ were retained in the final model, strongly suggesting that this is the best scale at which to assess the response of this beetle community to landscape heterogeneity. Area of water in the surrounding $250 \mathrm{~m}$ was the only other variable retained. On the CCA bi-plot (Fig. 4), the first axis $(\mathrm{CCA} 1, \mathrm{~F}=5.269, p<0.001)$ explained $10.2 \%$ of the variation and described a gradient away from more urban landscapes (as measured by manmade surface coverage) and those with greater extent of improved or amenity grassland. The second axis (CCA2, $\mathrm{F}=3.271, p=0.019)$ explained $6.3 \%$ of the variation and described a gradient from landscapes with large patches of scrub or scattered trees and larger amounts of water nearby, to drier landscapes with greater arable cover.

Beetle community composition was significantly spatially autocorrelated $(\mathrm{F}=1.560, p<0.001)$ with six PCNM retained in a reduced model explaining 26.6\% of beetle community composition. There was also a significant effect of sampling date and dung presence $(\mathrm{F}=$ 1.980, $p=<0.001)$ with Day1 $(\mathrm{F}=2.053, p=0.013)$, Day $2(\mathrm{~F}=2.669, p=0.002)$ and Stock $(\mathrm{F}=1.848$, $p=0.03$ ) together explaining $13.6 \%$ of beetle community composition.

In the variation partitioning, the contribution to adjusted- $R^{2}$ of space (significant PCNM), landscape (final model for landscape heterogeneity) and date / stock presence was $7.2 \%$, $5.8 \%$ and $4.5 \%$, respectively (Fig. 5). 5.3\% of the variation was shared between landscape and space, and $2.3 \%$ shared between all three fractions. Overall variation explained was estimated at $25.8 \%$. All individual fractions were significant after the other two were partitioned out (Space: $\mathrm{F}=1.5985$, $p=0.005$; Landscape: $\mathrm{F}=1.553, p=0.005$; Date/Stock: $\mathrm{F}=$ $1.674, p=0.012)$. 
Table 4 Summary of canonical correspondence analysis for the effects of landscape composition and configuration at three spatial scales on coprophilous beetle communities

\begin{tabular}{|c|c|c|c|}
\hline Model / Variable & $\mathrm{F}$ & $p$ & Explained \\
\hline Final Model & 2.430 & $<0.001$ & $23.3 \%$ \\
\hline Water 250 & 1.906 & 0.049 & $3.5 \%$ \\
\hline Manmade 500 & 3.961 & $<0.001$ & $7.3 \%$ \\
\hline Arable 500 & 2.257 & 0.008 & $4.2 \%$ \\
\hline ImpGrass 500 & 2.034 & 0.018 & $3.8 \%$ \\
\hline ScrubPatch 500 & 2.415 & 0.025 & $4.5 \%$ \\
\hline Composition (250, all terms) & 1.735 & $<0.001$ & $24.2 \%$ \\
\hline Configuration (250, all terms) & 1.485 & 0.011 & $24.3 \%$ \\
\hline Composition + Configuration $250(*=$ retained in combined model $)$ & 2.390 & 0.003 & $14.6 \%$ \\
\hline \multicolumn{4}{|l|}{ Wooded 250} \\
\hline Water $250^{*}$ & 2.243 & 0.031 & \\
\hline WoodPatch $250^{*}$ & 2.420 & 0.020 & \\
\hline OpenPatch $250^{*}$ & 2.278 & 0.024 & \\
\hline Composition (500, all terms) & 1.926 & $<0.001$ & $26.2 \%$ \\
\hline Configuration (500, all terms) & 1.554 & 0.003 & $25.1 \%$ \\
\hline Composition + Configuration 500 & 2.983 & $<0.001$ & $19.6 \%$ \\
\hline \multicolumn{4}{|l|}{$(*=$ retained in combined model $)$} \\
\hline Manmade $500 *$ & 3.092 & $<0.001$ & \\
\hline ImpGrass $500^{*}$ & 3.017 & 0.001 & \\
\hline Arable $500^{*}$ & 3.137 & 0.002 & \\
\hline \multicolumn{4}{|l|}{ Scrub 500} \\
\hline \multicolumn{4}{|l|}{ WoodDis 500} \\
\hline Scrub Patch 500* & 2.481 & 0.022 & \\
\hline Composition (1000, all terms) & 1.626 & 0.002 & $23.0 \%$ \\
\hline Configuration (1000, all terms) & 1.534 & 0.006 & $24.9 \%$ \\
\hline Composition + Configuration $1000(*=$ retained in combined model $)$ & 2.700 & $<0.001$ & $11.1 \%$ \\
\hline \multicolumn{4}{|l|}{ Garden 1000} \\
\hline Scrub $1000^{*}$ & 2.092 & 0.010 & \\
\hline \multicolumn{4}{|l|}{ Water 1000} \\
\hline GardenSize $1000^{*}$ & 3.410 & $<0.001$ & \\
\hline
\end{tabular}

\section{Discussion}

\section{Coprophilous beetle community}

For the whole coprophilous beetle community, urban distance band explained a relatively small proportion of the dissimilarity between sites, even when using a dissimilarity measure that deliberately gave a high weight to changes in abundance. This suggests that in urban areas this community represents a subset of the wider species pool found in surrounding agricultural landscapes and semi-natural habitat patches beyond, rather than a novel assemblage of species (cf. Hobbs et al. 2009; Kowarik 2011). It also appears that the coprophilous beetle communities in this study were not consistently homogenized by urbanisation as found e.g. by Magura et al. (2010) for ground beetles. This could be connected to dispersal ability: while some brachypterous ground beetles are reluctant to cross roads (Koivula and Vermeulen 2005) and may be absent from urban habitats
(Kegel 1990), all of the coprophilous species sampled in our study would have arrived at the traps on the wing.

Several urban sites were similar in species composition to some of the rural or fringe sites, whilst the overall abundance and richness was not significantly lower in urban sites. In other words, the 'best' semi-wooded urban green spaces can host a rich diversity of coprophilous beetle species, sometimes comparable to similar sites further from urban settlements. Similar patterns have been observed in other insect communities (Angold et al. 2006; Sadler et al. 2006; Croci et al. 2008b).

\section{Dung beetles}

Analysing data from the first and second visits separately revealed that patterns of activity in the beetle community were seasonally dependent (Finn et al. 1998). During the first visit, richness and abundance of all saprophagous beetles increased sequentially from urban sites through to rural. In the second visit 


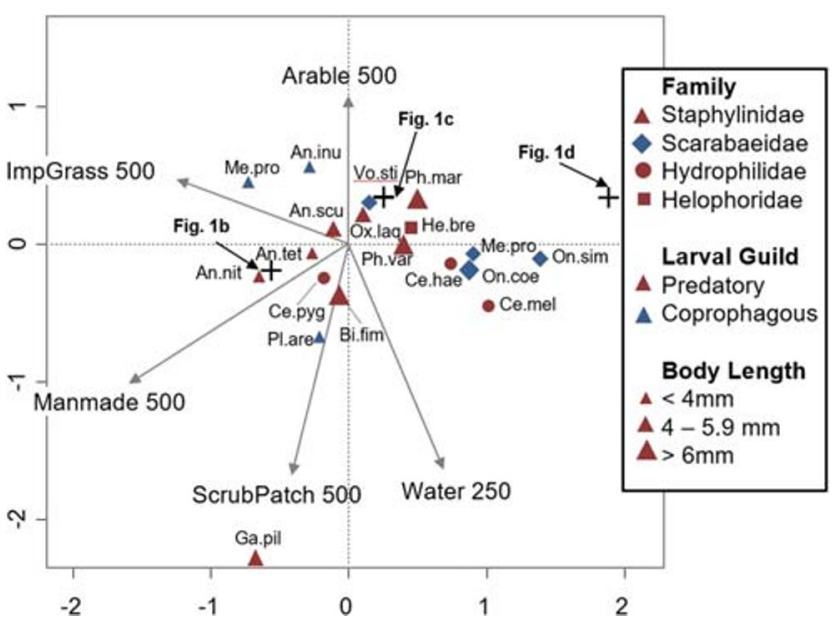

Fig. 4 Canonical correspondence analysis bi-plot for the effects of landscape variables on coprophilous beetle community composition. Length of arrows indicates the strength of correlation between predictor variables and constrained axes in the ordination. Optimal values of landscape variables for each species can be inferred by projecting the species location on the bi-plot perpendicularly onto the arrows. Abbreviations for species are listed in Table 2

there was little difference between the urban bands. This can be explained by the active season for dung beetles. These were significantly more abundant at rural sites but only during the first visit in late May and early June, when spring active dung beetles are still abundant (Finn et al. 1998). All of the larger saprophagous species collected were dung beetles belonging to the tribe Aphodiini or the genus Onthophagus. Dung beetles were recorded at only four urban sites during the study; these were all at sites on the outside edge of the Reading conurbation not completely surrounding by built-up areas. There are two possible reasons for this. Either urban areas present dispersal barriers for larger, slow-

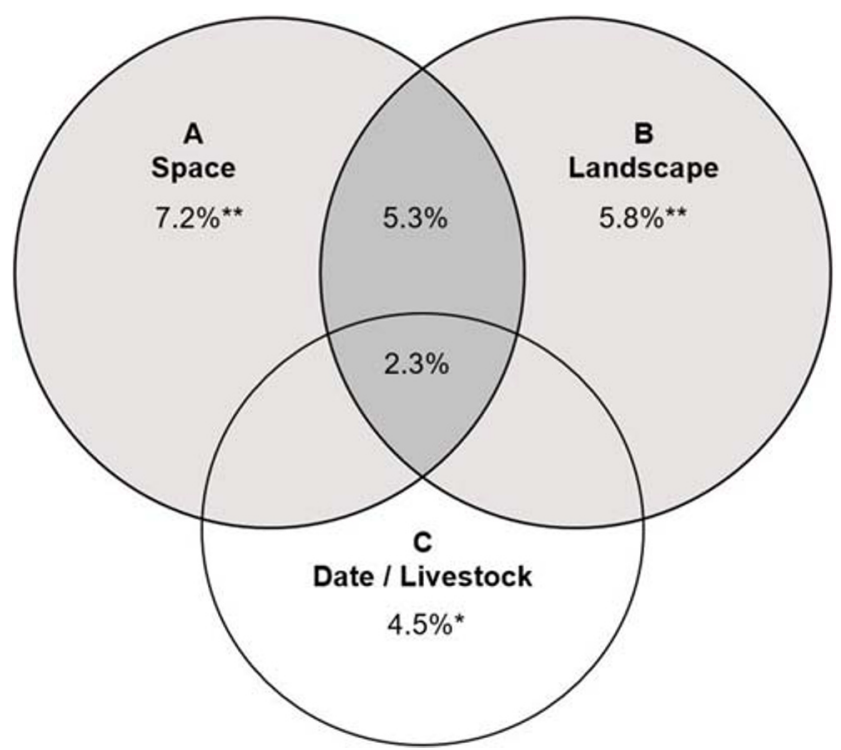

Fig. 5 Variation partitioning for the effects of space (PCNM), key landscape variables and survey date/livestock presence on coprophilous beetle community composition. Values are the proportion contributed to overall adjusted- $R^{2}$ by each fraction flying beetles (Magura et al. 2006; Sadler et al. 2006; Croci et al. 2008 b) or their populations are limited by lower resource availability in urban habitat patches (Gibb and Hochuli 2002). Previous casual observations of Aphodiini and Onthophagus species by the authors in a large urban green space in the study area (not sampled in the current study) possibly suggest that resources rather than dispersal limitations are the key limiting factor for urban dung beetles.

\section{Staphylinidae on dung}

Very few studies have examined the community of Staphylinidae on dung. Yamamoto et al. (2014) determined that the Staphylinid fauna on deer dung in Japan was dominated by a saprophagous Anotylus species. Three saprophagous Staphylinidae were found in the current study, of which two, Platystethus arenarius (like Anotylus in the subfamily Oxytelinae) and Megarthrus prosseni, were recorded at more than 10 sites, though none were nearly as abundant as the predatory Staphylinids that dominated the highest beetle counts in this study. Platystethus arenarius was present in all urban distance bands but was particularly common in urban sites during the second visit, associated with large patches of scrub in moderately wet landscapes. Megarthrus prosseni was also more frequent at urban sites, but in association with greater improved grassland cover. M. prosseni occurs in all kinds of decaying vegetation (Cuccodoro and Löbl 1997) and has been found frequently in horse dung in one UK county (Lane et al. 2002), which was used as the bait for traps in this study, though in a study in Poland it showed no preference for horse dung over cow (Mroczyński and Komosiński 2014). These species could be more common in the vicinity of urban areas because there tends to be more suitable habitat available, but following a similar experimental design Magura et al. (2013) found that the abundance and species richness of saprophagous Stapylinidae was higher in rural forests than urban ones. Alternatively, they may be experiencing competitive release in the absence of dung beetles or a release from certain predators (MacArthur and Levins 1964; Atkinson and Shorrocks 1981; Kruess and Tscharntke 1994).

\section{Predatory species}

The dominant species across all sites were two predatory Anotylus species. Considering the short trapping window of one hour, they were extremely abundant at some sites, with four counts of over 100 individuals recorded. Interestingly, all of the $100+$ counts were at urban (3) or fringe (1) sites. In terms of species richness, samples taken during the first visit would confirm the idea that predators can be limited by urbanisation (Hochuli et al. 2004; Rocha and Fellowes 2018), though the effect observed here was small, equating to one fewer active species at urban sites than rural ones. On the second visit there were no clear differences between urban, fringe and rural sites, 
suggesting that phenology of some coprophilous beetles may vary between rural and urban sites, as observed in butterflies (Dennis et al. 2017). Overall, there is no consistent evidence that urbanisation strongly impacts the abundance or richness of predatory beetles associated with dung and other patchy habitats. There is some evidence for a shift in the type of species that occur, however. Although dissimilarity analysis found no significant difference between distance bands, in the canonical correspondence analysis the smallest predators in each family (Anotylus spp., Cercyon pygmaeus) were mostly associated with higher manmade surface cover surfaces, while the larger species (Philonthus spp., larger Cercyon) tended to be associated with small amounts of manmade surfaces. The larger predators often occurred in association with dung beetles, perhaps because the presence of dung beetles indicates a site rich enough in dung or other patch habitats to support good numbers of all saprophagous insect larvae.

\section{Landscape heterogeneity}

The combination of higher numbers of dung beetles, larger predators and higher mean body size in rural areas (at least during the first visit, when the larger Scarabs were more active) suggests a shift along the urban gradient from larger specialist species to smaller generalists. This fits the trend frequently observed in ground beetles (Alaruikka et al. 2002; Gaublomme et al. 2008; Magura et al. 2006), even though, unlike ground beetles, this community of insects is unlikely to be limited by dispersal. The main exceptions to this trend were Bisnius fimetarius and Gabrius piliger, which favoured manmade surfaces, water and large patches of scrub, G. piliger very strongly so. Both are associated with any patch habitat that has a high concentration of insect larvae (Lott and Anderson 2011), but little other information is available regarding their ecology. The peri-urban areas of Reading have a good deal of scrub cover, often bordering large water bodies or rivers (Fig. 1); suburbs offer a heterogeneous environment that may be associated with high species richness (Blair and Launer 1997; Blair and Johnson 2008). This could explain the preference of some species for landscape types that fit this description and the higher predicted richness of predators at Fringe and Urban sites compared to Rural in our study area. Some of the trends observed in the beetle community may also be related to interactions with other coprophilous organisms, such as flies or fungi, which it is not possible to quantify with our data.

When landscape heterogeneity was considered at a $250 \mathrm{~m}$ radius, large patches of woodland and semi-natural grassland were identified as drivers of beetle community composition. They were not included in the final model as other landscape variables measured at $500 \mathrm{~m}$ better described the same gradient of variation in the beetle data. However, the fact that woodland and grassland patch sizes were not significantly different between urban distance bands suggests that larger patches of semi-natural habitat are valuable regardless of the location of the site on the urban gradient (Wolf and Gibbs 2004; Sadler et al. 2006); Söderström et al. (2001) also found a positive association between tree cover in the surrounding landscape and some dung beetle species recorded in grasslands. The amount of water within $250 \mathrm{~m}$ explained some of the variation on the second axis of the correspondence analysis. This may be linked to the preference of some species for damper soils or be a proxy for habitat quality close to water.

The inclusion of improved grassland in the final model might be expected if this cover type was linked to the presence of grazing livestock. In this case it was positively correlated with manmade surfaces, suggesting that the influential grassland type here was more likely to be amenity grassland, e.g., in parks or golf courses. Dung beetles were in fact associated with landscapes with relatively low improved grassland cover and the dung availability index was not included in any model. In this landscape they appear therefore to be more associated with semi-natural habitats, suggesting that livestock farming in the area does not support a high abundance of dung beetles (Hutton and Giller 2003; Webb et al. 2010).

Most of the key landscape variables identified describe landscape composition. The $500 \mathrm{~m}$ radius that best explained community composition is comparable to scales used in other landscape studies (Barbaro et al. 2007; Sjödin et al. 2008); in most of these cases measures of landscape composition or habitat amount were again more important than landscape, depending on the mobility of the species group. Given the long dispersal distances reported for some dung beetles (Roslin 2000), the effects of landscape configuration may operate at a larger scale than any measured here or may simply not be important for this community of beetles, especially as none of the species recorded is regarded as particularly specialist (Roslin 2001; Roslin and Koivunen 2001).

Landscape composition in this case is likely to be a proxy for the availability of suitable microhabitats, since the species community is formed around a patchy resource. The final proportion of variation explained by key landscape variables was not particularly high, especially after the portion attributable to spatial autocorrelation was removed, suggesting that local factors may be more important (Söderström et al. 2001; Philpott et al. 2014; Otoshi et al. 2015). The most important gradient in the beetle community is correlated with an increase in manmade surfaces, which is difficult to disentangle with the wider effects of distance from urban area. It is therefore not possible to be certain whether urbanisation, measured as an increase in impervious surfaces, is directly responsible for the trends observed in the beetle community or whether other features of the landscape that are correlated with urbanisation are more influential, as for habitat fragmentation and forest carrion beetles (Wolf and Gibbs 2004). The canonical correspondence analysis in any case usefully illustrates the character of landscapes that host different assemblages of coprophilous beetles, even if all the relationships described are not directly causal. 


\section{Summary}

This is probably the first study to consider the composition of the whole beetle community on dung on an urban gradient. Our hypothesis that coprophilous beetles are more abundant at rural sites (i) was true for saprophagous species but not for predators. Similarly,species richness (ii) differed only for dung beetles in the early season visit; estimates of total community species richness for saprophagous species suggest that richness is genuinely lower at urban sites while predators are richest at fringe sites. Body size (average body length) followed the expected pattern (iii) in the early season visit, driven by an absence of dung beetles from urban sites. Community composition differed significantly using a distance measure that gives a high weight to abundance, suggesting that our hypothesis (iv) is true depending on how community composition is defined.

While landscape features did not explain a large amount of variation in the coprophilous beetle community, there was some modification of the community by landscape heterogeneity at a $500 \mathrm{~m}$ radius that should be taken into account. Species displayed both positive and negative associations with manmade surfaces, again indicating a modification of the community along the urban gradient, while the abundance of others was correlated with other landscape components indicating an effect of heterogeneity beyond that associated with urbanisation.

The experimental design was deliberately robust to disturbance in urban areas, using traps deployed for short time periods that nonetheless detected a difference between the three urban distance bands. This could provide a useful model for other studies. A potential alternative would be to use private gardens as sampling sites, which has been successful for a number of other insect sampling studies, including in the same study area (Orros et al. 2015; Rocha et al. 2018). An interesting possibility in suitably undisturbed sites would be to directly assess ecosystem function by quantifying the decomposition rates of dung or other rotting vegetation, in parallel with observations of the species composition of the whole functional community of saprophagous insects and associated predators.

Acknowledgements We are grateful to Darren Mann and colleagues at the Oxford Museum of Natural History for providing support with identification of the specimens including access to reference collections.

\section{Compliance with ethical standards}

Conflict of interest The authors declare that they have no conflicts of interest.

Open Access This article is licensed under a Creative Commons Attribution 4.0 International License, which permits use, sharing, adaptation, distribution and reproduction in any medium or format, as long as you give appropriate credit to the original author(s) and the source, provide a link to the Creative Commons licence, and indicate if changes were made. The images or other third party material in this article are included in the article's Creative Commons licence, unless indicated otherwise in a credit line to the material. If material is not included in the article's Creative Commons licence and your intended use is not permitted by statutory regulation or exceeds the permitted use, you will need to obtain permission directly from the copyright holder. To view a copy of this licence, visit http://creativecommons.org/licenses/by/4.0/.

\section{References}

Alaruikka DM, Kotze DJ, Matveinen K, Niemela J (2002) Carabid beetle and spider assemblages along a forested urban - rural gradient in southern Finland. J Insect Conserv 6:195-206

Anderson MJ, Ellingsen KE, McArdle BH (2006) Multivariate dispersion as a measure of beta diversity. Ecol Lett 9:683-693

Angold PG, Sadler JP, Hill MO, Pullin A, Rushton S, Austin K, Small E, Wood B, Wadsworth R, Sanderson R, Thompson K (2006) Biodiversity in urban habitat patches. Sci Total Environ 360:196-204

Aschenborn HH, Loughnan ML, Edwards PB (1989) A simple assay to determine the nutrional suitability of cattle dung for coprophagous beetles. Entomologia Experimentalis et Applicata 53:73-79

Atkinson WD, Shorrocks B (1981) Competition on a divided and ephemeral resource:a simulation model. J Anim Ecol 50:461-471

Baker PJ, Harris S (2007) Urban mammals : what does the future hold? An analysis of the factors affecting patterns of use of residential gardens in Great Britain. Mammal Rev 37:297-315

Baker PJ, Thomas RL, Newson SE, Thompson V, Paling NRD (2010) Habitat associations and breeding bird community composition within the city of Bristol, UK. Bird Study 57:183-196

Baldock KCR, Goddard MA, Hicks DM, Kunin WE, Mitschunas N, Osgathorpe LM, Potts SG, Robertson KM, Scott AV, Stone GN, Vaughan IP, Memmott J (2015) Where is the UK's pollinator biodiversity? Biological Sciences, The importance of urban areas for flower-visiting insects. Proceedings of the Royal Society B p 282

Banaszak-Cibicka, W., Twerd, L., Fliskiewicz, M., Giejdasz, K., \& Langowska, A. (2018) City parks vs . natural areas - is it possible to preserve a natural level of bee richness and abundance in a city park? Urban Ecosyst 21 599-613

Barbaro L, Rossi J-P, Vetillard F, Nezan J, Jactel H (2007) The spatial distribution of birds and carabid beetles in pine plantation forests: the role of landscape composition and structure. J Biogeogr 34:652-664

Blair RB, Johnson EM (2008) Suburban habitats and their role for birds in the urban-rural habitat network: points of local invasion and extinction? Landsc Ecol 23:1157-1169

Blair RB, Launer AE (1997) Butterfly diversity and human land use: species assemblages along an urban gradient. Biol Conserv 3207:113-125

Blanchet FG, Legendre P, Borcard D (2008) Forward selection of explanatory variables. Ecology 89:2623-2632

Bohac J (1999) Staphylinid beetles as bioindicators. Agric Ecosyst Environ 74:357-372

Brinkhoff T (2018) United Kingdom: Urban Areas in England. Available at https://www.citypopulation.de/en/uk/cities/englandua/?cityid= 7246. Accessed 1 February 2020

Caballero U, León-Cortés JL (2012) High diversity beetle assemblages attracted to carrion and dung in threatened tropical oak forests in southern Mexico. J Insect Conserv 16:537-547

Carpaneto GM, Mazziotta A, Piattella E (2005) Changes in food resources and conservation of scarab beetles: from sheep to dog dung in a green urban area of Rome (Coleoptera, Scarabaeoidea). Biol Conserv 123:547-556

Cave RD (2004) Observations of urban dung beetles utilizing dog feces (Coleoptera: Scarabaeidae). Coleopt Bull 59:400-401

Croci S, Butet A, Clergeau P (2008a) Does urbanisation filter birds on the basis of their biological traits? Condor 110:223-240

Croci S, Butet A, Georges A, Aguejdad R, Clergeau P (2008b) Small urban woodlands as biodiversity conservation hot-spot: a multitaxon approach. Landsc Ecol 23:1171-1186 
Cuccodoro G, Löbl I (1997) Revision of the palaearctic rove beetles of the genus megarthrus Curtis (Coleoptera: Staphylinidae: Proteininae). J Nat Hist 31:1347-1415

DEFRA (2010) Agricultural census data for England. Accessed via EDINA (Edinburgh University data library)

Delgado de la Flor YA, Burkman CE, Eldredge TK, Gardiner MM (2017) Patch and landscape-scale variables influence the taxonomic and functional composition of beetles in urban greenspaces. Ecosphere 8

Dennis EB, Morgan BJT, Roy DB, Brereton TM (2017) Urban indicators for UK butterflies. Ecol Indic 76:184-193

Doležal P, Okrouhlík J, Davídková M (2016) Fine fluorescent powder marking study of dispersal in the spruce bark beetle, Ips typographus (Coleoptera: Scolytidae). European Journal of Entomology 113:1-8

Duff AG (2012) Beetles of Britain and Ireland. Volume 1: Sphaeriusidae to Silphidae. A.G. Duff publishing

Duflot R, Georges R, Ernoult A, Aviron S, Burel F (2014) Landscape heterogeneity as an ecological filter of species traits. Acta Oecol 56:19-26

Duflot R, Ernoult A, Aviron S, Fahrig L, Burel F (2017) Relative effects of landscape composition and configuration on multi-habitat gamma diversity in agricultural landscapes. Agric Ecosyst Environ 241:62-69

Dung Beetle UK Mapping Broject (2018) Dung Beetle UK Mapping Project: Identification. Available at https://dungbeetlemap. wordpress.com/finding-and-recording-dung-beetles/identification/. Accessed 15 May 2018

Egerer MH, Arel C, Otoshi MD, Quistberg RD, Bichier P, Philpott SM (2017) Urban arthropods respond variably to changes in landscape context and spatial scale. Journal of Urban Ecology 3:1-10

ESRI (2016) ArcMap 10.4. Environmental Systems Research Institute

Finn JA, Gittings T, Giller PS (1998) Aphodius dung beetle assemblage stability at different spatial and temporal scales. Appl Soil Ecol 10:27-36

Foster CW, Neumann JL, Holloway GJ (2019) Linking mesoscale landscape heterogeneity and biodiversity: gardens and tree cover significantly modify flower-visiting beetle communities. Landsc Ecol 34: 1081-1095

Gagic V, Bartomeus I, Jonsson T, Taylor A, Winqvist C, Fischer C, Slade EM, Steffan-Dewenter I, Emmerson M, Potts SG, Tscharntke T, Weisser W, Bommarco R (2015) Functional identity and diversity of animals predict ecosystem functioning better than species-based indices. Proc R Soc B Biol Sci 282:20142620

Gagné SA, Fahrig L (2011) Do birds and beetles show similar responses to urbanization? 21:2297-2312

Gaublomme E, Hendrickx F, Dhuyvetter H, Desender K (2008) The effects of forest patch size and matrix type on changes in carabid beetle assemblages in an urbanized landscape. Biol Conserv 141:2585-2596

Gibb H, Hochuli DF (2002) Habitat fragmentation in an urban environment: large and small fragments support different arthropod assemblages. Biol Conserv 106:91-100

Gittings T, Giller PS (1997) Life history traits and resource utilisation in an assemblage of north temperate Aphodius dung beetles (Coleoptera: Scarabaeidae). Ecography 20:55-66

Hanski I, Cambefort Y (1991) The dung insect community. Dung beetle ecology (ed. by I Hanksi and Y Cambefort) pp. 5-22. Princeton University Press, Princeton

Hobbs RJ, Higgs E, Harris JA (2009) Novel ecosystems: implications for conservation and restoration. Trends Ecol Evol 24:599-605

Hochuli DF, Gibb H, Burrows SE, Christie FJ (2004) Ecology of Sydney's urban fragments : has fragmentation taken the sting out of insect herbivory? Urban wildlife: more than meets the eye. (ed. by D Lunney and S Burgin) pp 63-69. Royal Zoological Society of New South Wales, Mosman, NSW

Hutton SA, Giller PS (2003) The effects of the Intesification of agriculture of agriculture on Nothern temperate dung beetle communities. J Appl Ecol 40:994-1007

Irmler U, Arp H, Nötzold R (2010) Species richness of saproxylic beetles in woodlands is affected by dispersion ability of species, age and stand size. J Insect Conserv 14:227-235
Jeffries DL, Chapman J, Roy HE, Humphries S, Harrington R, Brown PMJ, Handley LJL (2013) Characteristics and drivers of highaltitude ladybird flight: insights from vertical-looking entomological radar. PLoS One 8

Jones EL, Leather SR (2012) Invertebrates in urban areas : A review. Eur J Entomol 109:463-478

Kegel B (1990) The distribution of carabid beetles in the urban areas of West Berlin. In: Stork NE (ed) The role of ground beetles in ecological and environmental studies. Intercept, Andover, pp 325-329

Knapp S, Kuhn I, Schweiger O, Klotz S (2008) Challenging urban species diversity : contrasting phylogenetic patterns across plant functional groups in Germany. Ecol Lett 11:1054-1064

Koivula MJ, Vermeulen HJW (2005) Highwans and forest fragmentation - effects on carabid beetles (Coleoptera, Carabidae). Landsc Ecol 20: 911-926

Korasaki V, Lopes J, Gardner Brown G, Louzada J (2013) Using dung beetles to evaluate the effects of urbanization on Atlantic Forest biodiversity. Insect Sci 20:393-406

Kowarik I (2011) Novel urban ecosystems, biodiversity, and conservation. Environ Pollut 159:1974-1983

Krell FT (2007) Technical report 2007-6: Dung Beetle sampling protocols

Kruess A, Tscharntke T (1994) Habitat fragmentation, species loss, and biological control. Science 264:1581-1584

Lott DA (2009) Handbooks for the identification of British insects. Volume 12, part 5. The Staphylinidae (rove beetles) of Britain and Ireland. Scaphidiinae, Piestinae, Oxytelinae. Royal Entomological Society, London

Lott DA, Anderson R (2011) Handbooks for the identification of British insects. Volume 12, Parts $7 \& 8$ : The Staphylinidae (rove beetles) of Britain and Ireland. Oxyporinae, Steninae, Euasthetinae, Pseudopsinae, Paederinae, Staphylininae. Royal Entomological Society, London

Lövei GL, Horvath R, Elek Z, Magura T (2019) Diversity and assemblage filtering in ground-dwelling spiders (Araneae) along an urbanisation gradient in Denmark. Urban Ecosyst 22:345-353

Lowenstein DM, Matteson KC, Xiao I, Silva AM, Minor ES (2014) Humans, bees, and pollination services in the city: the case of Chicago, IL (USA). Biodivers Conserv 23:2857-2874

MacArthur R, Levins R (1964) Competition, habitat selection, and character displacement in a patchy environment. Proc Natl Acad Sci 51: $1207-1210$

Magura T, Tóthmérész B, Lövei GL (2006) Body size inequality of carabids along an urbanisation gradient. Basic Appl Ecol 7:472-482

Magura T, Lövei GL, Tóthmérész B (2010) Does urbanization decrease diversity in ground beetle (Carabidae) assemblages? Global Ecol Biogeogr 19:16-26

Magura T, Nagy D, Tóthmérész B (2013) Rove beetles respond heterogeneously to urbanization. J Insect Conserv 17:715-724

Magura T, Lovei GL, \& Tothmeresz B (2017) Edge responses are different in edges under natural versus anthropogenic influence : a metaanalysis using ground beetles. Ecol Evol 7:1009-1017

Magura T, Lövei GL, Tóthmérész B (2018) Conversion from environmental filtering to randomness as assembly rule of ground beetle assemblages along an urbanization gradient. Sci Rep 8:1-9

Manning P, Slade EM, Beynon SA, Lewis OT (2016) Functionally rich dung beetle assemblages are required to provide multiple ecosystem services. Agric Ecosyst Environ 218:87-94

Martínez-falcón AP, Zurita GA, Ortega-martínez IJ, \& Moreno CE (2018) Populations and assemblages living on the edge : dung beetles responses to forests-pasture ecotones. PeerJ 1-24

McIntyre NE, Rango J, Fagan WF, Faeth SH (2001) Ground arthropod community structure in a heterogeneous urban environment. Landsc Urban Plan 52:257-274

Merckx T, Souffreau C, Kaiser A, Baardsen LF, Backeljau T, Bonte D, Kristien I, Cours M, Dahirel M, Debortoli N, De Wolf K, Engelen 
JMT, Fontaneto D, Gianuca T, Govaert L, Hendrickx F, Higuti J, Lens L, Martens K, Matheve H (2018) Body-size shifts in aquatic and terrestrial urban communities. Nature 558:113-116

Morton D, Rowland C, Wood C, Meek L, Marston C, Smith G, Wadsworth R \& Simpson IC. (2011) Final Report for LCM2007 the new UK Land Cover Map. Centre for Ecology and Hydrology.

Mroczyński R, Komosiński K (2014) Differences between beetle communities colonizing cattle and horse dung. European Journal of Entomology 111:349-355

Natural England (2018) Priority Habitat Inventory (England). Used under Open Government Licence

Neter J, Kutner MH, Nachtsheim CJ, Wasserman W (1996) Applied linear statistical models, Fourth edn. Irwin, Chicago

Neumann JL, Griffiths GH, Foster CW, Holloway GJ (2016a) The heterogeneity of wooded-agricultural landscape mosaics influences woodland bird community assemblages. Landsc Ecol 31:1833-1848

Neumann JL, Griffiths GH, Hoodless A, Holloway GJ (2016b) The compositional and configurational heterogeneity of matrix habitats shape woodland carabid communities in wooded-agricultural landscapes. Landsc Ecol 31:301-315

Nichols E, Larsen T, Spector S, Davis AL, Escobar F, Favila M, Vulinec K (2007) Global dung beetle response to tropical forest modification and fragmentation: a quantitative literature review and meta-analysis. Biol Conserv 137:1-19

Nichols E, Spector S, Louzada J, Larsen T, Amezquita S, Favila ME (2008) Ecological functions and ecosystem services provided by Scarabaeinae dung beetles. Biol Conserv 141:1461-1474

Niemelä J (1999) Ecology and urban planning. Biodivers Conserv 8:119-131

Oksanen AJ, Blanchet FG, Friendly M, Kindt R, Legendre P, Mcglinn D, Minchin PR, Hara RBO, Simpson GL, Solymos P, Stevens MHH, Szoecs E, Wagner H (2016) Package 'vegan'. Available at: http:// cran.r-project.org/package=vegan

Ordnance Survey (2015). OS Mastermap Topography layer. Accessed via EDINA (Edinburgh University Data Library)

Orros ME, Thomas RL, Holloway GJ, Fellowes MDE (2015) Supplementary feeding of wild birds indirectly affects ground beetle populations in suburban gardens. Urban Ecosyst 18:465-475

Otoshi MD, Bichier P, Philpott SM (2015) Local and landscape correlates of spider activity density and species richness in urban gardens. Environ Entomol 44:1043-1051

Palmer MW (1990) The estimation of species richness by extrapolation. Ecology 71:1195-1198

Peres-Neto PR, Legendre P, Dray S, Borcard D (2006) Variation partitioning of species data metrices: estimation and comparison of fractions. Ecology 87:2614-2625

Philpott SM, Cotton J, Bichier P, Friedrich RL, Moorhead LC, Uno S, Valdez M (2014) Local and landscape drivers of arthropod abundance, richness, and trophic composition in urban habitats. Urban Ecosyst 17:513-532

Pinho P, Correia O, Lecoq M, Munzi S, Vasconcelos S, Gonçalves P, Rebelo R, Antunes C, Silva P, Freitas C, Lopes N, Santos-Reis M, Branquinho C (2016) Evaluating green infrastructure in urban environments using a multi-taxa and functional diversity approach. Environ Res 147:601-610

R Core Team (2017) R: A language and environment for statistical computing.

Radford JQ, Bennett AF (2007) The relative importance of landscape properties for woodland birds in agricultural environments. J Appl Ecol 44:737-747

Ramírez-Restrepo L, Halffter G (2016) Copro-necrophagous beetles (Coleoptera: Scarabaeinae) in urban areas: a global review. Urban Ecosyst 19:1179-1195

Rocha EA, Fellowes MDE (2018) Does urbanization explain differences in interactions between an insect herbivore and its natural enemies and mutualists? Urban Ecosyst 21:405-417

Rocha EA, Souza ENF, Bleakley LAD, Burley C, Mott JL, Rue-Glutting $\mathrm{G}$, Fellowes MDE (2018) Influence of urbanisation and plants on the diversity and abundance of aphids and their ladybird and hoverfly predators in domestic gardens. European Journal of Entomology 115:140-149

Roslin T (2000) Dung beetle movements at two spatial scales. Oikos 91: $323-335$

Roslin T (2001) Large-scale spatial ecology of dung beetles. Ecography 24:511-524

Roslin T, Koivunen A (2001) Distribution and abundance of dung beetles in fragmented landscapes. Oecologia 127:69-77

Rowland CS, Morton RD, Carrasco L, McShane G, O’Neil AW, \& Wood CM (2017) Land cover map 2015 (25m raster, GB). NERC Environmental Information Data Centre

Sadler JP, Small EC, Fiszpan H, Telfer MG, Niemelä J (2006) Investigating environmental variation and landscape characteristics of an urban-rural gradient using woodland carabid assemblages. J Biogeogr 33:1126-1138

Sattler T, Obrist MK, Duelli P, Moretti M (2011) Urban arthropod communities: added value or just a blend of surrounding biodiversity? Landsc Urban Plan 103:347-361

Sjödin NE, Bengtsson J, Ekbom B (2008) The influence of grazing intensity and landscape composition on the diversity and abundance of flower-visiting insects. J Appl Ecol 45:763-772

Smith EP, van Belle G (1984) Nonparametric estimation of species richness. Biometrics 40:119-129

Smith C, Clayden A, Dunnett N (2009) An exploration of the effect of housing unit density on aspects of residential landscape sustainability in England. J Urban Des 14:163-187

Snep RPH, Opdam PFM, Baveco JM, WallisDeVries MF, Timmermans W, Kwak RGM, Kuypers V (2006) How peri-urban areas can strengthen animal populations within cities: a modeling approach. Biol Conserv 127:345-355

Söderström B, Svensson B, Vessby K, Glimskär A (2001) Plants, insects and birds in semi-natural pastures in relation to local habitat and landscape factors. Biodivers Conserv 10:1839-1863

Theodorou P, Albig K, Radzevi R, Murray E, Paxton RJ, Schweiger O (2017) The structure of fl ower visitor networks in relation to pollination across an agricultural to urban gradient t e. Funct Ecol 31:838-847

United Nations (2014) World urbanization prospects: the 2014 revision, highlights. United Nations, Department of Economic and Social Affairs, Population Division

Vallet J, Daniel H, Beaujouan V, Rozé F, Pavoine S (2010) Using biological traits to assess how urbanization filters plant species of small woodlands. Appl Veg Sci 13:412-424

Vásquez-Vélez LM, Bermúdez C, Chacón P, Lozano-Zambrano FH (2010) Analysis of the richness of Staphylinidae (Coleoptera) on different scales of a sub-Andean rural landscape in Colombia. Biodivers Conserv 19:1917-1931

Vergnes A, Pellissier V, Lemperiere G, Rollard C, Clergeau P (2014) Urban densification causes the decline of ground-dwelling arthropods. Biodivers Conserv 23:1859-1877

Webb L, Beaumont DJ, Nager RG, McCracken DI (2010) Field-scale dispersal of Aphodius dung beetles (Coleoptera: Scarabaeidae) in response to avermectin treatments on pastured cattle. Bull Entomol Res 100:175-183

Webb J, Heaver D, Lott D, Dean HJ, van Breda J, Curson J, Harvey MC, Gurney M, Roy DB, van Breda A, Drake M, Alexander KNA, Foster G (2018) Pantheon - database version 3.7.6. Available at https://www.brc.ac.uk/pantheon/. Accessed 12 September 2018

Wolf JM, Gibbs JP (2004) Silphids in urban forests: diversity and function. Urban Ecosyst 7:371-384

Yamamoto S, Ikeda K, Kamitani S (2014) Species diversity and community structure of rove beetles (Coleoptera: Staphylinidae) attracted to dung of sika deer in coniferous forests of Southwest Japan. Entomological Science 17:52-58 